\title{
パルプ排液中の食用きのこの生育促進物質
}

\section{一一糖スルホン酸塩, リグニン・糖結合体のスルホン化物に効果}

サルファイトパルプはビスコースなどの原料となる溶 解用パルプおよび少量の製紙用パルプとして現在も年間 33〜36 万トンが生産されている. このサルファイトパ ルプをつくる方法では薬液の回収が行なわれないので, 主成分であるリグニンスルホン酸塩（46〜 54\% 対固 形 分）はセメント分散剤として大量に利用されているが約 $20 \%$ に達する還元糖および $22 \%$ 含まれる酸性糖（アル ドン酸十糖スルホン酸）はまったく利用されていない。

一方，食用きのこの生産量は 17.9 万トン/年, 金額と して 2,408 億円に達し, 年々増加の傾向にある. しか し, その生産方法はホダ木栽培, 推肥栽培, びん栽培な ど自然栽培に近い方法がとられ，大量生産を行ならには 栽培方法に改良の余地が多い。

サルファイトパルプ排液が食用きのこの生産量を増加 させることは比較的古くから知られていた. そして，そ の効果はリグニンスルホン酸塩によるものとされてき た. ところが，筆者らは偶然の機会から，それがリグニ ンスルホン酸塩によるものではなく混在する糖スルホ ン酸塩やリグニンと糖の結合体 (Lignin Carbohydrate Complex，または LCC) のスルホン化物のるつ促進作用 によること(1)を見いだした。

シイタケ菌 (Lentinus edodes) の生育を増大させるも のとして, 大豆, ニンジン, むやし, たけのこ, タマネ

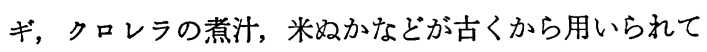
いるが，その有効成分については定見がない。一方，サ ルファイトパルブ排液の場合, これをゲルセロファン膜

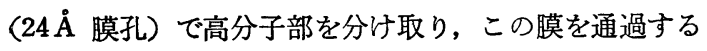
もののうち, 5 倍容エタノールで沈殿する区分に著しい 生育促進作用があり ${ }^{(2)}$, シイタヶ菌系では 5〜27 倍の収 量増を示した. 広葉樹由来のもの ( $\mathrm{S}$ 区分) と針葉樹由 来のもの (V区分) では菌により多少効果に差があるが, シイタケ菌ではV区分がS区分よりまさる，しかし， $5 \%$ 以上の添加は逆に収量減をもたらす。一方, 膜内に 残留したリグニンスルホン酸塩の高分子量区分では, む しろ菌の生育に阻害作用があることがわかった。
これらの結果は, ポテト培地を用い, 炭素源として蔗 糖 3\%を含む培地を標準としたもので，S 区分やV区 分を加える場合，全炭素源量は一定とし，蔗糖量を S区 分あるいはV区分で置きかえていった培地を用いた．至 適 $\mathrm{pH}$ は 5.5, スルホン酸の金属塩を形成するカチオン としては, $\mathrm{Ba}^{2+}$ は菌の生育を阻害するが, $\mathrm{Na}^{+} や \mathrm{Ca}^{2+}$ は促進し，とくに $\mathrm{Ca}^{2+}$ による効果がすぐれていること から、スルホン酸カルシウム塩の形で用いることとした.

シイタケ菌の子実体形成時に拗ける $\mathrm{S}, \mathrm{V}$ 区分の効果 を, 宮崎県の山地でミズナラをホダ木として試験した. ホダ木といらのは直径 $10 \sim 20 \mathrm{~cm}$, 長さ $80 \sim 100 \mathrm{~cm}$ の 丸太である. これにシイタケ菌系を植えつけ，その材の 成分を栄養として子実体を形成させる. 生育促進物質は そのとき菌と一緒にホダ木に打ち込まれる，ホダ木の種 類はブナ, コナラ, クヌギなどのブナ科, シデなどのカ バノキ科に限られ，たとえばアカマッなどは含まれる脂 肪酸がシイタケ菌の生育を阻害する. しかし，エノキタ ケ，ヒラタケなどは鋸屑培地を用いることができるの で，ホダ木を必要としない点，有利である.

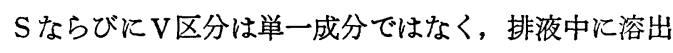
した木材成分のスルホン化物混合体であって，52〜60\% のリグニンスルホン酸，11〜17\% の糖，扣よび約 $20 \%$ のスルホン化糖およびアルドン酸を含む.

まず，SおよびV区分について疎水性クロマトグラフ ィーにより親水性部と疎水性のつよい数区分に分けたと ころ, 親水性部に活性がつょく, 親水性部を中性部と酸 性部に分けると，酸性部に活性があることがわかった。

また，中性オリゴ糖の種類にはあまり関係がなく，奇異 なことに分子量分布が均一であることが菌の生育に必要 で，特に単糖程度の大きさをもつ低分子部を含まないこ とが重要であった．そのほかスルホン化糖の存在が必要 であり，多量のリグニンスルホン酸塩を含むにもかかわ らずスルホン化糖が含まれない場合は，菌の生育促進効 果を示さない，また，これら区分にチッ素として $0.09 \%$ が含まれるにすぎないことから，含チッ素化合物が必須 


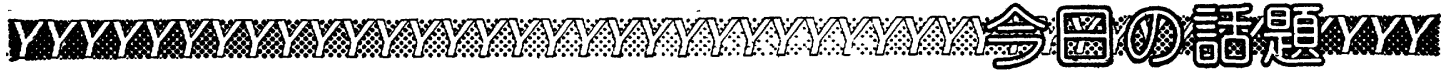

である可能性は少なく,オリゴマー程度の分子量をもつ スルホン化物でスルホン化糖を含むものと考えられる.

つぎに，木材成分を別々に取り出し，スルホン化後ゲ ルセロファン膜を通しエエタノールで沈殿する画分を集 めてモデルとし，これらについて促進効果を調べた(1). 試料として用いたものは, (1)広葉樹へミセルロースの主 体であるグルクロノキシラン, (2)針葉樹へミセルロース の主成分であるグルュマンナン，(3)針葉樹リグニンを代 表する MWL (摩砕リグニン), (4)リグニフィケーショ ンをうけた植物体に必ず存在する LCC (リグニン・糖 複合体)，ならびに(5)V画分中に含まれるリグニンと糖 の比率と同じ割合で(1)または(2)と(3)を混合した混合体で ある.これらの効果を検討した結果，興味ある事実がわ かってきた，すなわち，シイタケ菌の場合，V区分や $\mathrm{S}$ 区分に最も近い効果を示すのは LCC スルホン化物であ ること, 酸性糖や中性糖のスルホン化物も効果はあるが LCC には及ばないこと，および(5)は空試験以下の值, すなわち生育をむしろ阻害することである.

導入されるスルホン基量が多ければよいといらのでは なく適值があるらしいことすわかった. デンプン，セル ロース，グルクロノキシラン，ペクチンを上と同じよう にしてスルホン化し，ゲルセロファン膜で分別したもの を用いて調べた結果，グルクロノキシランのスルホン酸 塩がよく，最高収率を与えるイオウ含量は $4.6 \%$ であ った. デンプンの場合もイオウ含量の至適值は 4.6〜
$4.8 \%$ で阁様の傾向を示した(3)が，イオウの入りやすい セルロースではその值は $6.5 \%$ 前後であった.

分子量の影響をみるために, グルコマンナソ்スルホン 化物を用い, 数平均分子量 1,000 以下， $1,000 \sim 2,000$, $2,000 \sim 3,500,3,500$ 以上のものについて調べた結果, シイタケ, ヒラタケ, エノキタケのいずれの菌株でも分 子量 1,000 2, 000 の画分を与えたときの生育が最もよ く，同じ結果が LCC スルホン化物についても得られ $ホ^{(3)}$. S 区分やV区分についてもこの分子量範囲が有効 であることが確かめられ，実際に長野県で鋸㞕培地を 用いたエノキタケの生産に利用されつつある. 恐らく， 糖とリグニンが結合型として存在する部分に基づく界面 活性作用が役立っているのではないかと思われる．なぜ ならば，菌体内にとり込まれるときスルホン基は外れて いるからである，現在，単一成分としては得られていな いが，菌によっても効力に差があり，またシイタヶ，タ モギタケ，マッタケのように針葉樹起源のもの( $\mathrm{v}$ 画分) が利くものと, ヒラタケ, エノキタケのように広葉樹起 源の S 画分が高い活性を示す場合があって，末解決の点 が多い.

1）稲葉和功, 飯塚義富, 越島哲夫:木材学会誌，28，319 (1982).

2）越島哲夫：日本䤑造協会誌，79，851 (1984).

3）稲葉和功, 飯垗義富, 越島哲夫: 木材 学 会誌, 30, 251 (1984).

（越島 哲夫，京都大学木材研究所）

\section{生合成リズムをもつモモノゴマダラノメイガの性フェロモン}

\section{コーリングリズムとの“時間のずれ”に合目的性}

モモノゴマダラノメイガ (Conogethes punctiferalis GUENÉE）は，アジアを中心に広く分布する果樹その他の 害虫で，我が国には休眠性および加害植物の異なる 2 系 統が分布している、2 系統はそれぞれ果実系，マツ科系 と呼ばれ，果実系の幼虫は，モモ，クリなどの果樹の果 実を加害するのに対し，マッ科系の幼虫は, ゴョウマ ツ，トウヒ，モミなどのマツ科植物の針葉を加害する。 2 系統はしばしば混棲し，しかもその形態がきわめてよ く似ていることから，従来はモモノゴマダラノメイガの
名のもとに同一種として扱われてきたが，最近，2系焾 が生殖的に隔離されていることが明らかにされ，マッ科 系が新たにマッノゴマダラノメイガ (Conogethes sp.) の名で別種として扱われるようになった(1)

筆者らは，モモノゴマダラノメイガとマッノゴマダラ ノメイガの生殖隔離機構に興味をもち, 特にその要因の 一つと考学られる性フェロモンにスポットをあてて研究 を進めてきたが，その過程で，モモノゴマダラノメイガ の性フェロモンの生合成に関して興味ある結果が得られ 


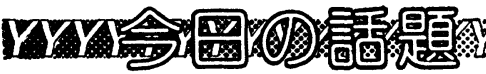

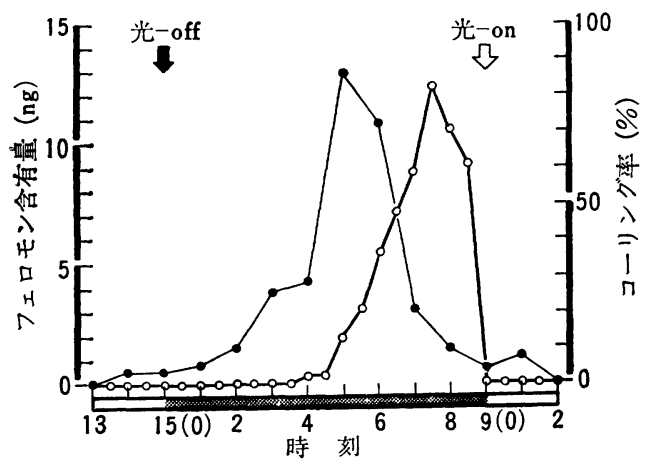

モモノゴマダラノメイガの性フェロモンの生合成リズムと コーリングリスムム

○:フェロモン含有量, $\bigcirc:$ : ーリング率. 明暗サイクルは 15 明 9 暗.

た.ここでは生殖隔離機構には触れず，生合成リズムに 限定して話を進めたい.

モモノゴマダラノメイガの未交尾雌は，暗期になると 静止した状態で翅をやや開き，その腙間から腹部を背面 側に持ち上げ，普段は収納されて見ることのできない腹 部末端の第 8～10 腹節を突出する. この行動は一般にコ ーリング (calling) と呼ばれ，コーリングを行なってい る雌に雄が誘引される.コーリングを行なっていない雌 には雄はまったく反応しないので，性フェロモンが第 8〜10 腹節に存在することがわかる.モモノゴマダラノ メイガの性フェロモンの構造決定は, 数千匹の未交尾雌 の第 8〜10 腹節の塩化メチレン抽出物を原料として行 なわれ，性フェロモンの一成分として $(E)$-10-hexadecenal が単離同定された

ところで, 未交尾雌から性フェロモンを抽出する過程 で問題になったのが，いつ抽出すれば最も効率が良いか であった. いろいろな時刻に抽出を行なってフェロモン 活性を雄の反応で調べてみると，抽出する時刻によって 雄の反応の強さに違いがみられ，暗期になってから数時 間経過した頃に抽出すると，雄の反応が最も高まること がわかった，一方，明期の抽出物には雄はほとんど反応 しなかったどうやら，性フェロモンの生合成に日周リ ズムが存在するらしい.

(E)-10-hexadecenal が単離同定された後, 生合成リズ ムを本格的に調べはじめた．1時間ごとに未交尾䧳の第 8～10 腹節を鋭利なハサミで切り取り，塩化メチレンで 1 分間抽出後，ただちに GLC で分析し，(E)-10-hexa- decenal に相当するピークを定量した. 図に羽化 3 日目 の未交尾雌の性フェロモンの含有量の日周変化を示し た. 予想どおり明瞭な生合成リズムが存在し, 消灯直後 から生合成が始まり，消灯後 5 時間を経過すると最大量 $13 \mathrm{ng}$ に達した，この生合成リズムは，抽出を行なった 羽化 2 日目から羽化 5 日目までの個体に連続して確認さ れたので，未交尾雌は交尾を行ならまで，日周リズムを 伴う生合成を絽り返すと考えられる。また，明期にはほ とんど性フェロモンが検出されず，消灯と同時に生合成 が始まることから，明から暗への光の刺激が生合成開始 の誘因の一つと考えられた.なお，稲の害虫の二カメイ ガでも性フェロモンの生合成が研究されているが, 二カ メイガの場合, 明から暗への光の刺激の他に, 頭部から 分泌されるホルモン様物質が生合成を制御しているとい う興味深い事実が明らかにされている(3).

さて，コーリングを行なら雌だけが性フェロモンを放 出することを前に述べたが，それでは，コーリングと性 フェロモンの生合成との関係はどうなっているのだろら か. そこで, 羽化 3 日目の未交尾雌 40 匹のコーリング 行動を 30 分ごとに記録し, 生合成リズムとの比較を行 なった (図).コーリングは, 消灯後 5 時間を経過すると 少数の個体が行ならようになり, その後漸次増加し, 消 灯後 7.5 時間を経過すると, $80 \%$ 以上の個体がューリ ングを行ならピークに達した。すなわち，2つのリズム の開始時期に 5 時間，ピークについては 2.5 時間の “時 間のずれ”があることが明らかになっだ(4). ニーリング が行なわれれば，当然，性フェロモンは放出されてしま い減少するだろらから，2つのリズムのピークの 2.5 時 間のずれがはたして正しいのか疑問が残るが，“開始時 間”の 5 時間のずれは, 昆虫の配偶行動上, きわめて合 理的な仕組みと考えられる.なぜならば, 性フェロモン が，その本来の機能を発揮するためには，生合成とュー

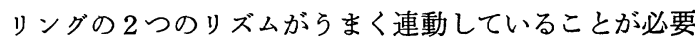
で，し何らかの原因で，コーリングを行なっているの に性フェロモンが存在しなければ, 雌は雄を誘引するこ とができず，ひいては種の存続も危うくなるだろう．

生合成リズムとコーリングリズムの “時間のずれ”。 メカニズムに対する考え方は，以下の 2 通りが考えられ る. 1つは, 脳あるいは他の中枢神経系により，2つの 


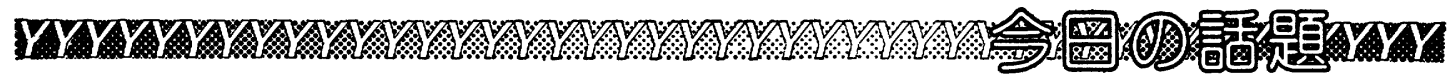

リズムがあらかじめずれるように設定されていること， 他の 1 つは, 性フェロモンが生合成されて体内に溜まる ことによる刺激がューリングを誘起することである.こ の問題についてはまだ結論が出ていないが, 何らかの方

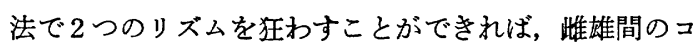
ミュニケーションを摜乱することも可能と考えられる.

以上述べてきたように, 昆虫の性フェロモンの生合成 や, ューリング行動との時間のずれを解明することは, 従来の殺虫剂とは作用機構の異なる新しい殺虫剂を創造
する可能性を秘めており, 今後の研究の発展が待たれる 分野である.

この研究は, 筆者が東京大学在学中に, 松本義明教授の指導 のもとに行なわれたものである.

1) 昆野安彦: 遺伝, 39 (12), 44 (1985).

2) Y. Konno, K. Arai, K. Sekiguchi \& Y. Matsumoto : Appl. Ent. Zool., 17, 207 (1982).

3）日井健二，笹川浩美，内海恭一，栗原政明，深見順一，田 付貞洋 : 第 29 回応動昆大会講要 (1985).

4) Y.Konno: Appl. Ent, Zool., 投稿中.

（昆野 安彦, 農林水産省農業環境技術研究所）

\section{太つたサンマと瘦せたサンマ}

\section{一一美味しいのは遺伀的に脂質含量を高める能力のある“系統”}

体質的に太りやすい人とそうでない人がいるように 同じ種類の魚にも太りやすい魚とそうでない魚がある. 秋の代表的な味覚であるサンマを食べるとき，脂のよく のった美味しいサンマとそうでないサンマがあるのは皆 さんの体験しているところであろう．高等動物の肥満に ついては，マウスなどにおいて精密な代謝実験が行なわ れ，系統的に肥満（太り）をコントロールする主働遺伝 子や多くの微動遺伝子群（ポリジーン）が見つけだされ ており, 肥満現象は栄養条件などの後天的影響を受けな がらも，先天的な遺伝の影響の強い形質であることがわ かっている(1).

魚については一部の淡水魚で飼育実験により肥満の遺 伝性が調べられているが(2)，私たちが日常口にする魚の ほとんどは野生のものであり，人為的に管理されたもの ではないことから，魚類の場合 “系統”というような考 え方は今までなじみが薄かった。“系統”といら考方方 を進める一つの方法として，飼育できることが前提にな るが, 海産魚, 特にサンマのような外海域を回遊する魚 では，飼育すること自体が非常に難しく，それを自然に 近い状態で飼育するなどほとんど不可能に近い。このよ らな理由で, 回遊性魚類を飼育し系統間に拉ける違いを 調べた研究はほとんど行なわれていない. 今回, アイン ザイム遺伀子を指標とした集団遺伝学的手法により系統 的な観点からサンマの肥満現象を調べる機会を得たの で,その結果について述べよう.

分布域, 成長, 耳石などの生態学的調査から, 秋に北
海道, 東北の沖合を南下するサンマ群はいくつかの群か ら成っているのではないかと考えられていた時代もあ ったが，近年は遺伝的にかなり均一なものとされてい た (3). しかし, サンマ群の肥満や脂質含量の変化を調べ てみると不連続なところがあり, どうみても 1 つの群と は思えないような現象が観察された. そこで，いったい サンマ群は遺伝的に均一な集団なのか, それとも遺伝的 に異なるいくつかの群から構成されているのかを調べる ことにした. サンマ群の集団構造を調べるために，でき るだけ広い場所から，またできるだけ多くのサンプルを 無作為に抽出することにより, 時空間的に連続した標本 を採集した. これらのサンマ標本について，MDH（リ

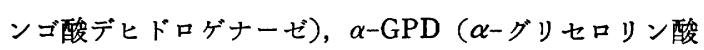
デヒドロゲナーゼ), IDH (イソクエン酸デヒドロゲナー ゼ), PGM(ホスホグルュムターゼ)の変異のある 4 つの アイソザイム遺伝子を用い, 集団構造の解析を行なった. 1979 年から 1981 年の 3 年間, 北海道から東北の沖 合, 南北約 $1,500 \mathrm{~km}$, 東西約 $3,000 \mathrm{~km}$ の広い海域から サンプリングを行なった結果, 1979 年には 8 つ, 1980 年には $5 つ, 1981$ 年には 6 つのそれぞれ遺伝的に異 なる小集団が日本近海に来遊していたことがわかっ た (4,5).このように, サンマ群は遺伝的に均一な集団か らできているのではなく, 年によって来遊群の数が変化 していた.さらに，日本のはるか沖合の中央太平洋に 7 月から 8 月頃に分布していたサンマのいくつかの小集団 が 9 月から 10 月頃には北海道の沖を通過し, 11 月から 


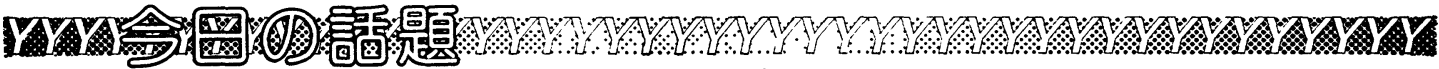

12 月頃までには常磐の沖に達しており，遺伝的連続性 によりサンマ群の移動も確かめられた(6).

さて，遺伝的に分けられた小集団と肥満度および脂質 含量とを比較してみると，小集団間で明らかに肥満度の 高い群と低い群，すなわち脂質含量の高い群と低い群に 分けられる. 両群とも， 8 月から 12 月にかけて南下す る間に同じ割合で脂質含量が減少する. 一方, 肥満度の 変化についても同様の傾向が認められる. 魚の場合, 肥 漶度は次のように求められる。

肥満度 $=$ 体重 $\div$ 体長 $\times 1000$

これによれば, 同じ体長の魚では体重が大きいほど肥満 していることになり，直接脂肪の付き具合をみているの ではないが，肥満度と脂質含量との間には高い相関関係 がある(7)ことから、サンマにおける太った群とそうでな い群は, 脂質含量の高い群と低い群を意味している.

漁獲量の多い年には太っているサンマが多く, 漁獲量 の少ない年には瘦せているサンマが多いとされている. 実際, 1967 年から 1981 年の漁獲量の多い年の太ったサ ンマの割合は $76.6 \%$ ，漁獲量の少ない年のその割合は $59.1 \%$ であり，漁隻量の多い年には太ったサンマが多 い. 各年の肥満と餌の量や生殖腺の発達状態とには明ら かな関係が認められないことから, 遺伝的に肥満する群 は集団が大きくなる特性を持っているのではないかと考 壳らる.

魚類の肥満は，ヒトと同じように遺伝的な影響だけで なく環境的な影響も受けている.サンマでは 8 月から 9 月に千島列島周辺や北海道東岸で獲られるサンマの脂質 含量は $20 \%$ 以上のものが多い.このサンマが親潮（寒 流）前線の南下に伴い，餌の少ない黑潮（暖流）域に達 する 11 月から 12 月の常磐沖で獲られる頃には, 生殖 腺が発達し始め, 脂質含量は低下し, 10\% 以下のものが 多くなる. サンマの脂質含量は, 分布している場所の慨
の量や水温, 生理状態によって大きく変化し, 環境的な 影響を受けていることは，このよらな現象からみても確 かである。

ヒトの肥澫の主な原因は, 皮下の脂肪層の増加による ことが知られている．魚では脂肪の貯蔵部位として，大 きくみて 2 つの型がみられる. 1 つは皮下（特に腹部） 脂肪層にトリグリセリドなどの中性脂肪をためるタイ プ，もら 1 つは肝蔵部に多くの脂肪をためるタイプであ る.前者のタイプとしては，今まで述べてきたサンマ， イワシ類, サバ類などの赤身の浮魚が，また後者のタイ ブそしては，タラ類などの白身の底棲魚があげられる(8). 魚類も十分な栄養を与えられ，また成長や成熟などの消 費エネルギーをさほど必要としない時期になると，吸収 エネルギーのらち生活エネルギーを除く分が蓄積に回さ れ, 脂肪の増加, 肥満となって表われる、サンマの太り やすい群はそうでない群に比べて，遺伝的に魚体組織細 胞における蓄積脂質であるトリグリ七リドの合成, 蓄積 能力が高いと考えられる.つまり, 肥満し, 脂がよくの った美味しいサンマは持って生まれた体質によるのであ る.

1) E. L. Green : "Biology of the Laboratory Mouse", Dover Pub., 1966, p. 670.

2) T. Gjedrem : Aquaculture, 33, 51 (1983).

3）小達 繁: 北大北洋研業績集, 特別号, 353 (1977).

4）原 素之, 木島明博, 藤尾芳久: 東北水研報告, 45,1 (1982).

5）原 素之, 木島明博, 藤尾芳久: 東北水研 報告, 45,19 (1982).

6）木島明博, 原 素之, 藤尾芳久 : 東北 水 研 報 告, 46,39 (1984).

7) M. Hara, K. Ito \& M. Hata: Tohoku J. Agri. Res., $34(3,4), 65$ (1984).

8）土屋蜻彦: “水産化学”, 恒星社, 1962, p. 447.

（原 素之, 水産庁東北区水産研究所）

\section{ダイズ多収への挑戦}

\section{$500 \mathrm{~kg} / 10 \mathrm{a}$ 水準の生産を可能にする栄養生理的研究に期待}

ダイズは多収をあげにくい作物といわれ，その原因と しては次のようなことがあげられる. (1)ダイズの場合， 子実に多量のタンパク質を集積するという作物的特性か
ら，水稲のよらに子実にデンプンを集積する作物に比べ て, 初期光合成産物からみた収穫物転換効率 ${ }^{(1)}$ が低く, 初期光合成産物で収量を比較すると, ダイズの $10 \mathrm{a}$ 当 


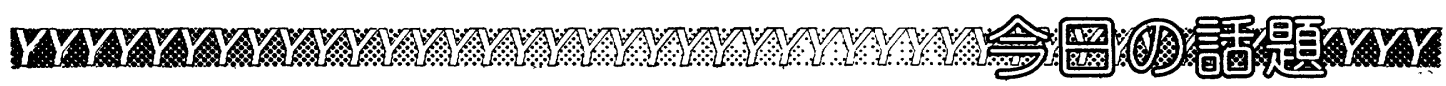

たり $400 \mathrm{~kg}$ および $500 \mathrm{~kg}$ の収量は, 水稲の場合の650 $\mathrm{kg}$ 抢よび $800 \mathrm{~kg}$ のきわめて高い収量に相当する. (2)広 葉作物であることから，多肥あるいは密植によって葉面 積を增大させても，ある一定値以上では光ェネルギーの 利用効率が向上しにくいといら受光態勢の問題がある. (3)栄埳生長と生殖生長の重複する期間があり, 光合成産 物に対する茎葉, 萊, 根, 根粒の 4 者間の競合が起こる. (4)多収のための理想生育型が明らかでない.

そこで筆者らは，収量水準を停滞させている原因を， 量的因子（乾物生産量）と質的因子（ダイズ体栄養）の 2 つの側面に着目して, 実際に $400 \mathrm{~kg} / 10 \mathrm{a}$ 水準および $500 \mathrm{~kg} / 10 \mathrm{a}$ 水準のダイズを供試して, 収量構成要素を 量的因子および質的因子の関連で解析して, ダイズ多収 へのアプローチを試みた。 収量構成要素から見たダイズ の収量は, 一般的には,

面積当たりの着萊数 $\times 1$ 萊内粒数 $\times$ 子実百粒重 によって表わされる. その中で, 収量との関係が高く変 異係数が大きいのは, 面積当たりの着萊数であり， 1 萊 内粒数および百粒重の変異係数は比較的小さかった。 こ のことは, 着萊数を増加させることが収量の増加に直接 的に結びつくことを示している．さらに，面積当たりの 着萊数を乾物生産とダイズ体の栄養状態との関連で解析 するために次式に分解した(2).

面積当たり着萊数 $=$ 面積当たり総節数 $\times$

\section{有効節数割合 $\times 1$ 節萊数}

その中で, 萊の着生する部位である節数を示す総節数は, 主に乾物生産量によって決定される（総節数と乾物重の 相関が比較的高い(3)）と考兄られる. 一方，着萊効率を 示すと考兄られる有効節数割合拉よび 1 節萊数を決定し ている要因については明らかではないが，着萊効率の高 いダイズの萊数決定期における光合成産物（炭水化物） 量および濃度がきわめて高く ${ }^{(2)}$ ，ダイズ体の栄養状態が 大きく関与していることが考兄られる.この点関して

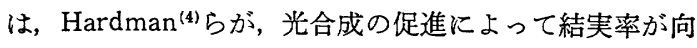
上して增収すること， 石塚 ${ }^{(5)}$ は落花落莢の原因が光合成 産物の不足によることを指摘していることから，着萊効 率の向上については，主に source 能が制限因子になっ ているといえる.

このように，収量を規制しているのは着萊数であり，
着萊数は，主に乾物生産量（量的因子）とダイズ体の栄 養状態（質的因子）によって規制されている，また，収 量水準によっても量的因子之質的因子の規制の程度が異 なり, $400 \mathrm{~kg} / 10 \mathrm{a}$ 水準までは, 主に量的因子の向上で達 成が可能であるが, $500 \mathrm{~kg} / 10 \mathrm{a}$ 水準では, 量的因子とと もに質的因子の向上が必要条件であると考兵られる.

現在, 現場に打汀る低収性の最大の要因は, 乾物生産 量（総節数）の不足に起因している(6). そこで，収量向” 上には，第一義的に乾物生産量を増加させることが必要 であり,これは肥培管理（早植, 密植, 多肥）によりあ る程度は可能である. 乾物生産量を高めることは, 栄㽰 生長量の抬大と萊の着生部位である節数を増加させるこ とで意義がある. しかし, 乾物重を高めることにより多 収を得る方法では限界が認められる. 収量の停滞は主 に, 過繁茂による群落の光合成量の低下, 倒伏や分枝切 損による節数の減少によって起こることが考兄られる.

このように, 乾物生産で多収 ( $400 \mathrm{~kg} / 10 \mathrm{a}$ 水準)を得よ うとする場合は，その限界值を明らかにして対策を実施 するために, 生育診断技術の導入が重要である.

最近, 沖積( ${ }^{(8)}$, 火山灰土壌 ${ }^{(7)}$ のダイズを対象にした開 花期に括ける生育診断法が報告されている.これによれ ば，開花期に和ける適正限界值は，沖積土堹では 400 $\mathrm{kg} / 10 \mathrm{a}$, 火山灰土境では $250 \mathrm{~kg} / 10 \mathrm{a}$ で, それ以上の乾 物生産量では, 草姿の乱れ, 倒伏程度が著しく, 着萊効 率の低下から収量的に不利（特に沖積土壤）であること が指摘されている. 以上より, 生育診断を実施して, 乾 物生産量に着目して安定的に得られる収量は $400 \mathrm{~kg} / 10$ a 前後であると考えられ，この水準の収量は，今までに 構筑された肥培技術の導入で達成可能である.

一方, $500 \mathrm{~kg} / 10 \mathrm{a}$ 水準のダイズは, 量的因子と質的因 子のバランスが特に重要で, どちらか一方が久けても実 現し得ないと考えられる. 筆者ら (2,8) が解析した 500 $\mathrm{kg} / 10 \mathrm{a}$ 水準のダイズにおける量的・質的因子から見た 特性として次のようなことがあげられる. (1)乾物生産パ ターンが後半型であった. (2)収檴指数が $400 \mathrm{~kg} / 10 \mathrm{a}$ 水 準の 45〜50 に対して 55〜60 できわめて高い值であっ た. (3)葉身の窒素濃度が生育後期まで高く, しか子窒素 集積量も生育後期に多かった. (4)炭水化物の濃度および 集積量が開花期以降高まる傾向で, 特に葉柄では顕著で 


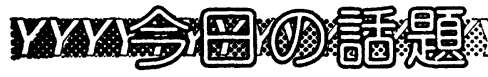

あった. (5) source 能が低下する登熟中期以降, 残って いる茎葉からの窒素および炭水化物の転流が円滑であっ た.

このような点から, ダイズ多収に必要な窒素, 炭水化 物の供給メカニズムについて解析する必要があり, 今後 の研究の方向としては次のようなことが考兄られる. (1) sink である萊, 子実の增大に最も寄与率の高いステー ジの光合成産物の供給量を増加させる技術の開発. (2)ダ イズ体内に拈ける適正な炭水化物濃度/窒素濃度比につ いて. (3)根粒による窒素固定量を高める技術の確立. (4) 栄養診断技術の開発. (5)多収ダイズへの窒素の追肥技術 の確立. (1)については, ダイズの場合, 栄養生長と生殖 生長の競合による光合成産物の不足が推察されることか ら, 栄養生長から生殖生長への転換メカニズムの解析を はかることが重要である. Bauerら (9)は, 開花期のダイズ に TIBA を散布して栄養生長を抑制するとともに，光 合成産物济対する競合を軽減して収量を高めることを指 摘している (収量水準は $300 \mathrm{~kg} / 10 \mathrm{a}$ 前後である). (3) ついては, $500 \mathrm{~kg} / 10 \mathrm{a}$ 水準のダイズに対する根粒の寄 与率は明らかでない。 また, Brunら(10)は根粒に対する炭
水化物量を增すと窒素固定量が増加することを指摘して いることから，登熟後期に拈ける光合成産物の根粒への 配分が重要なことを示唆している. (2)，(4)，(5)について の報告は，まだきわめて少ない。

以上のように, $500 \mathrm{~kg} / 10 \mathrm{a}$ 水準のダイズの 栄養生理 的な研究は，ようやく始まった段階であり，上記の問題 が解決されれば安定的に $500 \mathrm{~kg} / 10 \mathrm{a}$ レベルのダイズの 生産も可能になると考えられ，今後の研究の進展が望ま れる。

1) J. Yamaguchi : J.Facul. Agric. Hokkaido Univ., 59, 59 (1978).

2）藤井弘志, 安達忠弘, 桃谷 英, 鈴木 武, 大沼 彪, 阿 部吉克, 今野 周：土肥誌，投稿予定 (1986).

3）藤井弘志，荒垣憲一，中西政則：土肥誌，56，336(1985).

4) L. L. Hardman \& W.A. Brun: Crop Sci., 11, 886 (1971).

5）石塚潤爾：北海道農誌研報, 101, 51 (1972).

6) 藤井弘志 : 土肥誌, 56, 153 (1985).

7) 石井和夫：農及園, 58, 1394 (1983).

8）藤井弘志，今野 周，阿部吉克，大沼 彪：土肥誌，投稿 予定 (1986).

9) M. E. Bauer, T. G. Sherbeck \& A. J. Ohlrogge : Agron. J., 61, 603 (1969).

10) W. A. Brun : Agron. Abstr., 31 (1972).

（藤井 弘志，山形県立農業試験場）

\section{ペプチドグリカン結合力ダベリンの細菌表層膜における機能}

\section{—Selenomonas ruminantiumの表層膜に生育に必須の力ダベリンが存在}

ポリアミンは，一級または二級アミノ基を 2 個以上有 する直鎖の脂肪族フミンで，すべての生体内に存在する 塩基性物質である. 非常に簡単な化学構造を有する化合 物ではあるが，多岐にわたり重要な生物活性を示すこと が報告されてきた．たとえば，(1)細胞増殖および細胞分 裂と密接な関係を持つこと，(2DNA，RNA および蛋白 質の合成を促進する作用を持つこと，(3)種々の酵素活性 の調節に関与していること, (4)細菌の表層膜の安定性を 維持する作用を持つことなどである(1). しかし，これら に関する数多くの研究報告にもかかわらず，ポリアミン は生体内で, 単に有機カチオンとして他の金属イオンと 類似した機能だけを持つのか, それともるっと重要な役 割を果たしているのかがはっきりしないのが現状である. 特に, 細菌の表層膜の安定性にポリアミンが関与してい る可能性を示唆する報告は, いずれも細菌のプロトプラ
ストやスフェロプラストの低浸透圧液中での破壊が外か らの添加ポリアミンにより抑制されるといら現象を論じ たもので，上記の事実が生体内に拈けるポリアミンの生 理的役割を反映している直接的証拠になっていない.こ こで, もしポリアミンが細菌の表層膜あるいは表層構造 物全体の一部分として久くことのできない一構成成分と してのみ存在する系があれば, ポリアミンの欠損変異株 の使用あるいは, ポリアミンの合成阻害剤を使用しての 実験から，表層膜におけるポリアミンの生理的機能を直 接証明することが可能となる.

1980 年に, グラム陰性で偏性嫌気性菌である Selenomonas ruminantium の細胞壁ペプチドグリカンには, 一般のグラム陰性菌に共通して見られるリポ蛋白質を欠 き,あたかもこれに取って替わるが如くポリアミンの一 種のカダベリンが共有結合して存在することが，筆者ら 
により見いだされた (2 4). しかも,カダベリンはリジンか ら構成的に細胞質内で合成され, 続いて細胞質膜上でペ プチドグリカンリピド中間体にカダベリン：リピド中間 体転移酵素で転移されることが明らかにされた ${ }^{(5,6)}$.こ うして, 本菌が細胞表層におけるポリアミンの生理的意 義を解明する上で有用な系として浮かび上ってきた.

大腸菌において, ペプチドグリカン結合リポ蛋白質欠 損株 ( $m l p$ 株, あるいはlpo 株) は, EDTAに対し高感 受性を示すことや, 低濃度の $\mathrm{Mg}^{2+}$ 存在下では, ペプチ ドグリカン上で外膜は安定した構造を保てないことが知 られている(7,8). また，無細胞系によるペプチドグリカ ン上での外膜の再構成には，リポ蛋白質結合ペプチドグ リカンが必要であることが知られている(9). このことか ら, 大腸菌においては, リポ蛋白質は表層において外膜 が安定して存在するのに必須の構成成分であることが明 らかである. 一方, S. ruminantium においては, リポ蛋 白質が欠如しているにもかかわらず，EDTA に対し顕 著な感受性を示さず, 安定した二重膜構造をとってい る. 本菌の表層膜の安定には，ペプチドグリカンに結合 したカダベリンが関与している可能性が充分考えられ る.これを証明するために, 筆者らはカダベリン合成阻害 剂ジフルオロメチルリジン (DFML) を使用して選択的 に本菌のカダベリン合成を阻止する系を作製した(10)。 ず, S. ruminantium における DFML のリジン脱炭酸 酵素 (LDC) 活性に及注す影響を無細胞系で検討した結 果, DFML は本菌の LDC 活性を特異的に非可逆的に 阻害することが明らかになった．次に，無細胞系にお けるカダベリン：リピド中間体転移酵素活性に拈ける DFML の影響を調べたところ，DFML ( $5 \mathrm{~mm})$ は，そ の活性をまったく阻害しなかった。

ペプチドグリカンに共有結合したカダベリンが本菌の 表層膜において重要な生理的意義を持つと仮定すると, 培地に添加された DFMLにより本菌の生育が阻害さ れることが予想される. そこで，本菌の生育に対する

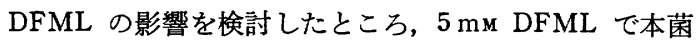
の生育が顕著に阻害され, 特に DFML 添加 11 時間後 には急激な溶菌現象が見られた。培養液の濁度がまだ増 加している対数後期では，ほとんぞの菌が伸長したり, 膨れた異常形態を示した。これをさらに超薄切片の電子
顕微鏡下で観察した結果，ペプチドグリカンから外膜 が剝がれた部分やペプチドグリカンが破れた部分が数 多く見られた.ところが，培地にカダベリン (1 mM)を DFML と同時に添加した場合, DFML はまったく生育 に影響を与えなかった. さらに, DFML ( $5 \mathrm{mM}$ )を加え た培地で菌を生育させ，阻害効果が現われた後に $1 \mathrm{mM}$ のカダベリンを添加すると, 菌の生育の急速な回復が見 られた. しかも, 表層構造は健全なものに回復してい た.しかし，カダベリンのかわりに $\mathrm{Mg}^{2+} や \mathrm{Ca}^{2+}$ を培 地中に添加しても, DFML による生育阻害は解除され なかった。 これらの実験結果は，DFML 処理菌におけ る生育阻害, 異常表層膜構造および溶菌現象が, ペプチ ドグリカンに护けるカダベリンの欠損に起因している可 能性を示唆している.

筆者らはこの可能性を調べるため, DFML 処理菌お よびカダベリンによって生産を回復した菌からそれぞれ ペプチドグリカンを調製し, それらの組成を無処理菌か らのそれと比較検討した. 無処理菌の場合, アラニン, ジアミノピメリン酸, カダベリン, ムラミン酸およびグ ルコサミンのグルタミン酸に対するモル比は, 1.9: $1.1: 0.8: 0.9: 1.0$ であるのに対し, DFML 処理菌の 場合は, そのモル比は, 2.0:1.0:0.04:0.9:1.0であ り，明らかにカダベリン含量が極端に少なくなっている ことがわかった. 一方, 回復菌の場合は, それぞれのモ ル比は無処理菌と同じく正常値を示した. 以上の結果か ら，DFML 処理菌に見られる異常生育および溶菌現象 は, DFML が LDC 活性を非可逆的に阻害したため, リジンからのカダベリンの合成が阻害され, 結果的にペ プチドグリカンヘのカダベリンの供給が断たれ, カダベ リン欠損ペプチドグリカンが合成されたために起こった ものであると結論された.

なお, DFML 処理菌の溶菌現象については, その機 構に関しては実験的証拠はないが，不完全なペプチドグ リカン上での外膜の虚弱な構築が, たとえば, 自己溶解 酵素やリン脂質分解酵素の誘導を促し, その結果, ペプ チドグリカンあるいは膜の破壊ぶ起こったものと考えら れる.

大腸菌においてペプチドグリカン結合型リポ蛋白質を 欠く変異株は, 低 $\mathrm{Mg}^{2+}$ 存在下で生育させた場合, 表層 


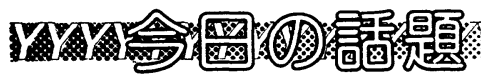

膜に大きなブレッブを形成したり，ペリプラズムに存在 する物質が細胞外に瀮出して，正常な生育ができないこ とが知られている. しかし，この欠損株に見られるこれ らの現象は, 高濃度 $\mathrm{Mg}^{2+}$ 存在下では見られず, 正常な 生育が観察される. 一方, S. ruminantium においては, カダベリン欠損ペプチドグリカンを合成するような条件 を与えると, たとえ高濃度 $\mathrm{Mg}^{2+}$ 存在下でも正常な生育 は不可能になる.これらの事実から，S.ruminantium のペプチドグリカン結合カダベリンの生理作用は, 本菌 においては大腸菌や他のグラム陰性菌に見られるリポ蛋 白質の表層における生理作用よりも，もっと重要な意義 を持っていると言える.

このペプチドグリカン結合カダベリンが, 外膜のいか なる物質と密接に関連しているかはまだ明らかではない が，可能性として，たとえば外膜の蛋白質やリン脂質お よびリポ多糖体とイオン結合などできわめて密接に関わ り合っていることが考えられる.これは，カダベリンの 結合したペプチドグリカン上での S. ruminantium およ び大腸菌外膜構成成分の再構成実験を試みることにより 明らかになるであろら。ささらに, 遺伝子操作により, リ ピド中間体：カダベリン転移酵素の大腸菌発現ベクター へのクローニングと, この遺伝子のリポ蛋白質欠損大腸 菌における発現を試みることにより, ペプチドグリカン
結合ポリアミンのさらに立ち入った生理的意義を大腸菌 で検討することが可能である. 現在まで, ポリアミンの 生体内に括ける機能に関する研究は, プトレシン, スペ ルミジンおよびスペルミンが主体を占めてきたが，ここ で述べたようにカダベリンの細胞表層におけ打る役割が明 らかになった現在, ポリアミンの生体内における機能 を，新しい観点から眺めることができるよらになったと いえよう.

1) C. W. Tabor \& H. Tabor: Microbiol. Rev., 49, 81 (1985).

2) Y. Kamio \& H. Takahashi : J. Bacteriol., 141, 899 (1980).

3) Y. Kamio, Y. Itoh, Y. Terawaki \& T. Kusano: $J$. Bacteriol., 145 (1981).

4) Y. Kamio, Y. Itoh \& Y. Terawaki : J. Bacteriol., 146, 49 (1981).

5) Y. Kamio, Y. Terawaki \& K. Izaki : J. Biol. Chem., 257 3326 (1982).

6) Y. Kamio \& Y. Terawaki : J. Bacteriol., 153, 658 (1983).

7) D. W. Yem \& H. C. Wu : J. Bacteriol., 133, 1419(1978).

8) H. Suzuki, U. Nishimura, S. Yasuda, A. Nishimura, M. Yamada \& Y. Hirota : Mol.Gen. Genet., 167, 1(1978).

9) H. Yamada \& S. Mizushima: J. Biochem., 81, 1889 (1977).

10) Y. Kamio, H. Pösö, Y. Terawaki \& L. Paulin : J. Biol. Chem., in press.

(神尾 好是, 信州大学医学部)

\section{イソギンチャクのクマノミ誘引物質}

\section{一トリプタミン, チラミンなど複数の物質の微妙な混合によつて活性が発現}

浅海の岩礁やサンゴ礁にすむ海水魚クマノミは, 種に よって定まっている 1 種から 2 種のイソギンチャク（宿 主イソギンチャク）としか共生しないことが知られてい る(1). クマノミは危険が身にせまるとイソギンチャクの 触手の中に逃げこむ. イソギンチャクは触手にある刺胞 から毒液を出して獲物をとらえるが，クマノミはその毒 液の害を受けない.この共生現象は広く知られており, 古くから多くの生物学者の研究対象となってきた. クマ ノミの生活史はまず, 親魚がイソギンチャクの近くの岩 㓌に卵を産みつけるところから始まる，産みつけられて 1 週間後くらいて餒化した稚魚は，まず近くにイソギン チャクがいるにもかかわらずそこには入らず，海面まで
浮上する. そして, 海面で約 10 日間浮遊生活を過ごし た後, 海底へ移動して宿主イソギンチャクと共生を始め る. この過程で稚魚は嗅覚によって宿主イソギンチャク を識別し探索することが知られており(2), 孵化位置から の移動距離は数百メートルに達することもある. 稚魚は

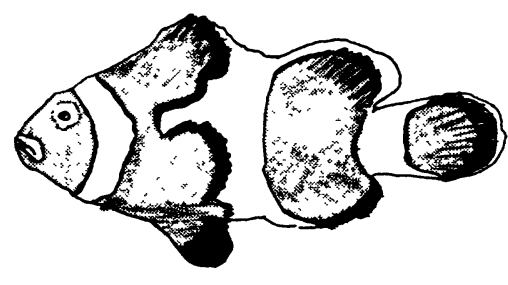

カクレクマノミ 


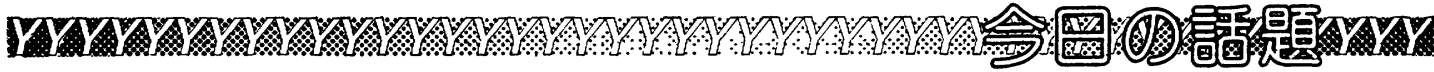

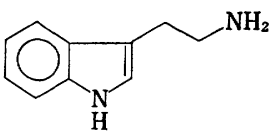

トリプタミン

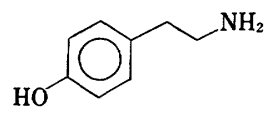

チラミン
宿主イソギンチャクの発する化学物質を高感度で認知 し，その流れに逆って泳ぐことにより宿主イソギンチャ クを探し当てていると考えられる.これに関与する化学 物質についてはこれまでほとんど解明されていなかった が，今回，琉球列島（特に八重山諸島）で最もポピュラ 一なカクレクマノミ (Amphiprion ocellaris) とハタゴイ ソギンチャク (Stoichactis kenti) について, 化学誘引物 質の単離同定が試みられた。

誘引活性の有無は次のようなバイオフッセイ法で調べ ることができる．長さ $2 \mathrm{~m}$ ，高さ $5 \mathrm{~cm}$ のアクリル製容 器の一端から海水を流し, 流速と水位を一定に保つ. 魚 は15 分間, 下流の $25 \mathrm{~cm}$ 以内の所に閉じ込めた後，乙 きいを除去しても上流に泳いで行かないものを用いてア ッセイを行なう．海水に溶かした試料を入水口付近に滴 下し，滴下開始とともに魚の位置を記録し始め, 16 分間 の記録で魚が入水口に接近した頻度を求め，誘引活性の 有無を判定する.

さて，沖䋥の黒島で採集したハタゴイソギンチャクの 分泌液をまず酢酸エチルで抽出したところ，誘引活性の 大部分が抽出された. これを数種のカラムクロマトグラ フィーで分画精製し，活性画分が得られた，しかし，溶 出画分すべてが誘引活性を示すということがしばしばあ り，分画が進むにつれて活性の総量も低下する傾向にあ った．活性画分は主にアミン類を含み，フェネチルアミ ソ，スフィンゴシン, トリプタミン, チラミンが検出さ れた。このらち, フェネチルアミン，スフィンゴシンは まったく活性を示さなかった. トリプタミンは誘引活性 こそ示さなかったが,カクレクマノミに対し $7.8 \times 10^{-7} \mathrm{M}$ でワッギング行動（体を左右にくねらせる行動）を誘 発した. ワッギング行動は天然の分泌液を試験した場合 やフィールドでも観察されるので, トリプタミンはカク レクマノミに宿主イソギンチャクの存在を認識させる役 割があるものと思われる. 一方，チラミンは誘引活性を 示し, $1.3 \times 10^{-6} \mathrm{M}$ でカクレクマノミを誘引した. しか し, 天然の分泌液中には約 $1.1 \times 10^{-9}$ M のチラミンしか

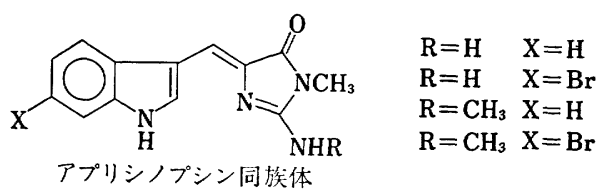

含をれておらず，チラミンだけで分泌液の誘引活性を説 明することはできない，チラミンをまったく含まない画 分も弱いながらも誘引活性を示し，トリプタミンの添加 によって活性は 100 倍以上に増加する．これは，トリブ タミンが誘引の増感作用を有し，分泌夜中でも誘引活性 に深く関与していることを示している.これらの外にも 弱い活性画分は多数存在したが，それらも単独の投与よ り混合することによって誘引活性が增強するといら傾向 を示した。こうしたことから，カクレクマノミはハタゴ イソギンチャクの分泌する複数の成分を誘引物質として おり，ちょらど我々が鰻の臭いに誘引されるように，多 数の成分の微妙な混合によって天然の誘引活性が発現し ているものと思われる.

ところで，上記の誘引物質はクマノミ類の種特異的な 宿主イソギンチャクの住み分け現象にどのように関わっ ているのであろうか.これを調べるため, 上述の組み合 わせとは異なるものとしてシライトインギンチャク (Rdianthus kuekenthali) のハナビラクマノミ(Amphiprion perideraion)誘引物質について調査したところ, トリプタミンの活性と同様に，ハナビラクマノミに共生 時の行動を誘発する物質としてアプリシノプシン (aplysinopsin）同族体が単離された、 シライトイソギンチャ クの分泌液はハタゴイソギンチャクの場合と異なり，比 較的少数の誘引物質しか含まず，その主成分についても 単離に成功したが，構造は未定である.

シライトイソギンチャクの分泌液にはトリプタミンも チラミンも含まれているが，ハナビラクマノミは両者に 対して何の行動も示さない，一方，ハナビラクマノミ同 様にシライトイソギンチャクと共生するナミクマノミ (A. clarkii) の場合は，シライトイソギンチャクの分泌 液には誘引されるが，ハナビラクマノミの主活性成分や フプリシノプシン同族体には何の反応も示さない，ナミ クマגミは分泌液中の他の物質を誘引物質として使って いることがわかる。

バナビラタマリミの共生相手にはシライトイソギンチ 


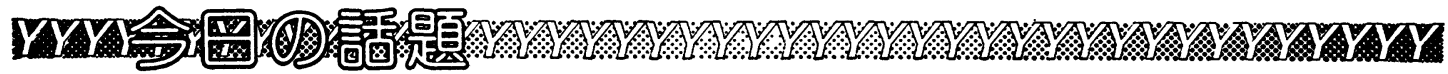

ヤクの他にセンジュイソギンチャク（Radianthus macrodactylus）があるが，この分泌液中には先の八ナビラ クマノミ活性物質は 2 成分とも含まれていない.すなわ ち, ハナビラクマノミは宿主イソギンチャクによって誘 引物質を使い分けていることになる。

このように, クマノミとイソギンチャクの組み合わせ によってそれぞれ多様な誘引物質が存在する. 1 種のイ ソギンチャクに対して, 普通 $2 \sim 3$ 種のクマノミが共生
できるが，クマノミはそれぞれ種によって異なった誘引 物質を利用しており，また，同種のクマノミでも宿主イ ソギンチャクの種に対応する複数の誘引物質を嗅ぎ分け ていることがわかってきた.

1）松下 甲，岡本一志：動水誌，22-2，27 (1980).

2) K. Miyagawa \& T. Hidaka : Proc. Japan Acad., 56, Ser. B, 356 (1980).

（村田 道雄, (財)サントリー生物有機科学研究所 (現・東北大学農学部))

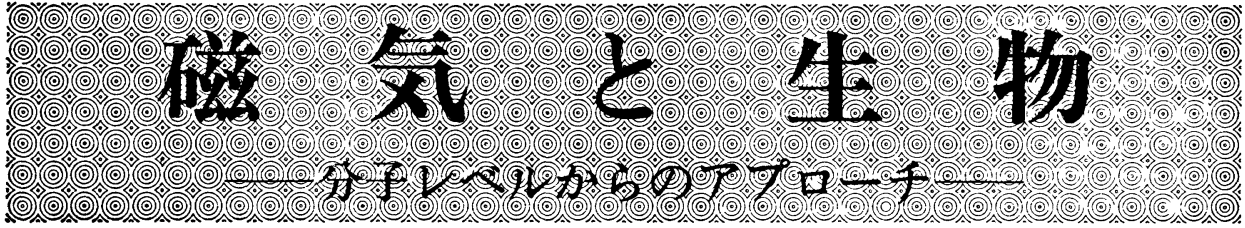

\section{高橋不二雄 著}

\section{A5判 $/ 140$ 頁 $/ 2000$ 円}

\section{〈主要目次〉}

1. 磁気の基礎

1 1 1 磁場と磁気エネルギー

1-2 Zeeman効果, スピンースピン相互作用

1-3 磁気流体力学, 交番磁場, パルス磁場

2. 磁場配向

2-1 カエル視細胞外節

2-2 好塩菌紫膜

2-3 クロレラ, クロロプラスト

2-4 鎌状赤血球など

3. 磁場と化学反応

3-1 酵素活性

3-2 クロロフィルの光励起

3-3 フィプリンのゲル化
4. 磁性感覚

$$
\begin{aligned}
& 4-1 \text { 走磁性微生物 } \\
& 4-2 \text { 磁気に応答する動物 } \\
& 4-3 \text { 磁性感覚 } \\
& \text { 4-4 神経と磁場 }
\end{aligned}
$$

5. 生物への磁場の影響

$$
\begin{aligned}
& 5-1 \text { 微生物 } \\
& 5-2 \text { 動植物 } \\
& 5-3 \text { 畽瘍細胞 } \\
& 5-4 \text { 細胞選別における磁性の利用 }
\end{aligned}
$$

6. 磁気の利用と安全性

6-I NMR と臨床検査

6-2 磁場に対する指針 